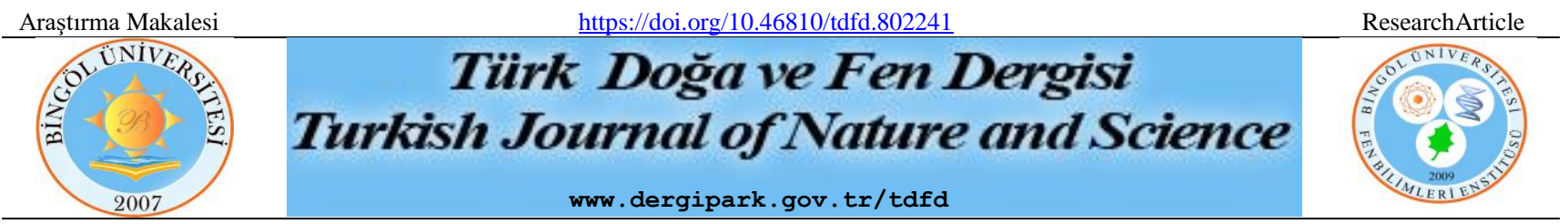

\title{
Lor Peynirlerinde Fekal Kaynaklı Esherichia coli, Klebsiella pneumoniae Aranması ve Antibiyotik Direnç Profillerinin Belirlenmesi
}

\author{
Hüseyin TANIŞ ${ }^{1 *}$, Burcu AYTAÇ ${ }^{1}$, Erdal ERTAŞ², Ashabil AYGAN ${ }^{1}$ \\ ${ }^{1}$ Kahramanmaraş Sütçü İmam Üniversitesi, Fen Edebiyat Fakültesi, Biyoloji Bölümü, K.Maraş, Türkiye \\ ${ }^{2}$ Kilis 7 Aralık Üniversitesi, Fen Edebiyat Fakültesi, Moleküler biyoloji ve Genetik Bölümü, Kilis, Türkiye \\ Hüseyin TANIŞ ORCID No: 0000-0002-2012-7864 \\ Burcu AYTAÇ ORCID No: 0000-0002-4823-0169 \\ Erdal ERTAŞ ORCID No: 0000-0002-4043-5960 \\ Ashabil AYGAN ORCID No: 0000-0003-4936-9872
}

*Sorumlu yazar: huseyintanis23@hotmail.com

(Alınış: 30.09.2020, Kabul: 01.05.2021, Online Yayınlanma: 25.06.2021)

\begin{abstract}
Anahtar
Kelimeler

Lor peyniri,

Antibiyotik

Direnç,

E.coli,

K.pneumoniae

Öz: Bu çalışmada Kahramanmaraş’ta satışa sunulan 30 adet lor peyniri örneği mikrobiyolojik olarak incelenmiş, 30 örneğin 29 'unda Esherichia coli ve Klebsiella pneumoniae'nın üremesi görülmüştür ve antibiyotik dirençlilikleri belirlenmiştir. Çalışmada 74 adet E.coli suşu tanımlanırken 17 adet K. pneumoniae suşu saptanmıştır. İzole edilen E.coli suşlarında, en yüksek oranda cefuroxime $(\% 88)$, en düşük oranda ise sefepime $(\% 1)$ olarak tespit edilmiş ancak levoflaksasine karşı direnç tespit edilmemiştir. İzole edilen $K$. pneumoniae suşlarında ise en yüksek oranda direnç \%70' olarak tetraksikline karşı, en düşük ise seftriaksona karş1 \%23 olarak tespit edilmiştir. $\mathrm{Bu}$ bulgular üretimden tüketiciye ulaşıncaya kadar lor peynirlerinin kontaminasyona uğradığını göstermiş ve örneklerden tespit edilen $E$. coli ve $K$. pneumoniae suşlarının antibiyotik dirençliliklerinde artış olduğunu ortaya koymuştur. $\mathrm{Bu}$ sonuçlar peynir üretimi, saklanması, antibiyotik kullanımının kontrollü olmasının ve satış koşullarının daha iyi şartlarda olması gerektiğini ortaya koymuştur.
\end{abstract}

\section{Investigation of Faecal Originated Esherichia coli, Klebsiella pneumoniae in Curd Cheese and Their Antibiotics Resistance Profile}

Keywords

Curd cheese,

Antibiotic

resistance,

E.coli,

K.pneumoniae

\begin{abstract}
In this study, microbiological qualities of 30 samples of curd cheese, at retail on various conditions in Kahramanmaraş market, were investigated and the presence of Escherichia coli and Klebsiella pneumoniae contamination was observed in 29 of the 30 curd cheese samples and the antibiotic resistance of these microorganisms was determined. During the study, 74 E. coli strains and $17 \mathrm{~K}$. pneumoniae strains were detected. Among the isolated E.coli strains, the highest resistance $(88 \%)$ was against cefuroxime while the lowest resistance $(1 \%)$ was against cefepime and no resistance was detected against levofloxacin. On the other hand, the highest resistance $(70 \%)$ was against tetracycline and the lowest resistance $(23 \%)$ was against the ceftriaxone among the $17 \mathrm{~K}$. pneumoniae strains. These findings showed that the curd cheeses were contaminated from production to consumer and E. coli and K. pneumoniae strains identified in the samples have considerably increased antibiotic resistance. The study revealed that cheese production, storage, antibiotic use should be controlled and sales conditions should be in better conditions.
\end{abstract}

mikroorganizmalar tarafından kontaminasyona açıtır.

\section{GIRIŞ̧}

Tüm dünyada tüketilen ve çok sayıda çeşidi bulunan peynirin halk sağlığı açısından mikrobiyolojik kalitesi önemlidir. Sütün sağılması, taşınması ve peynir yapımı aşamalarında hijyen kurallarına yeterince dikkat edilmediğinde patojen ve patojen olmayan birçok Kaynatılmayan sütten yapılan peynirde bulunan mikroorganizmalar peynirin yapısında değişime neden olacağı gibi tüketilmesi sonucunda da gida zehirlenmelerine ve patojenlerin kontaminasyonu sonucu bazı hastalıklara yol açabilmektedir. Salamura peynirlerde yüksek tuz konsantrasyonu ile saprofit ve patojen mikroorganizmaların üremesi engellenmiş olur. 
Fakat lor peynirinde böyle bir durum olmadığ süre içerisinde tüketilmediği zaman mikroorganizmaların hızla çoğalabileceği bir ortam oluşmaktadır [1].

Süt ürünlerinden biri olan lor peyniri üretimi hızlı ve maliyeti ucuz olduğundan tüketicinin fazla tercih ettiği bir peynir türüdür. Lor peyniri faydalı Streptococcus, Lactococcus, Leuconostoc ve Lactobacillus gibi laktik asit bakterilerinin yanı sira E. coli, Listeria monocytogenes, Salmonella spp., Enterobacter aerogenes, Enterobacter cloacae, Citrobacter spp., Klebsiella aerogenes, $K$. pneumoniae gibi pek çok hastalık yapıcı bakteri türü ile kontamine olabilmektedir. $\mathrm{Bu}$ mikroorganizmalar içerisinde, en zararlı grubu koliform bakterileri oluşturmaktadır [1]. Koliform grubu bakteriler içerisinde Enterobacteriacae familyasına ait $E$. coli gibi türlerin varlığ aşamalarında yetersiz hijyen uygulamalarından kaynaklı bir kontaminasyonun olduğunun göstergesidir ve insan sağlığı açısından tehlike arz etmektedir. Bu familyanın diğer bir üyesi Klebsiella türleridir. $\mathrm{Bu}$ türlerden özellikle K. pneumoniae florada daha az sayıda olsa da patojen olması geniş spektrumlu beta laktamaz enzimi üreterek antibiyotiklere karşı direnç geliştirmesi bakımından önem arz etmektedir.

$\mathrm{Bu}$ bakterileri barındıran süt ürünleri tüketildiğinde hastalık yapıcı etmenlerin yanı sıra barındırdıkları antibiyotik direnç özellikleri de insan vücudundaki kommensal-zararsız mikroorganizmalara aktarılması mümkündür. Bunun sonucunda hastalıklara karşı uygulanan antibiyotik tedavileri yetersiz kalmakta ve antibiyotiklere olan direnç her geçen gün artmaktadır [2]. TSE lor peynirini, peynir altı suyu tekniğine göre asitlendirilmesi ve pastörizasyon koşullarında 1 sıl işlem uygulanmasından elde edilen kendine özgü renk, tat ve aroması olan mamul olarak tanımlamıștır (TSE 13358, 2008). Lor peyniri ve benzer peynirlerin üretim yöntemleri, 1s1 etkisiyle serum proteinlerinin, özellikle $\alpha$ laktalbumin ve $\beta$-laktoglobulin proteinlerinin, denatüre edilip toplanması esasına dayanmaktadır [3].

Uygun koşullarda üretilmeyen ve satışa sunulmayan lor peyniri halk sağlığ 1 açısından mikrobiyolojik bir tehdide dönüșebilir ve peynirin raf ömrünü kısaltabilir. Bu sebeple peynir gibi süt ürünlerinin mikrobiyolojisi ve hijyeni çok önemlidir [4]. Gıda zehirlenmeleri ile ilgili ülkemizdeki duruma göz attığımızda, Türkiye İstatistik Kurumu (TUIK) verilerine göre, 1993-2005 y1lları arasında gıda kaynaklı olarak 108.246 kişi hastaneye yatmış ve 1993-2002 yılları arasında 1702 ölüm vakası tespit edilmiştir [5]. Ancak ülkemizde üretilen sütün \%90 gibi önemli bir k1smı teknik bilgi ve modern aletlerden yoksun mevsimlik mandıralarda köy kadınlarının elinde işlenmektedir [6]. Bu durum ise gıda kaynaklı pek çok hastalığa neden olabilmektedir.

Gıdalarda mikrobiyolojik analizler birçok araştırmacı tarafından sürekli yapılmaktadır ve mikrobiyal etmenlerin varlığı çoğunlukla kültür temelli olarak tespit edilebilmektedir [7]. Enterobacteriaceae üyelerinin tespiti için desoxycholate'lı besiyerlerinin yanında kromojenik/florojenik özellikli besiyerleri mevcuttur.
EMX agar, C-EC-MF agar, Chromocult Coliform, CHROMagar ECC, E. coli / Coliform, HiCrome ECC bunlardan bazılarıdır [8]. MDCLS (Modifiye Desoxycholate-Citrate-Lactose-Sucrose) [9] laktoz pozitif Enterobacteriaceae üyelerinin izolasyonu için geliştirilmiş selektif bir besiyeridir. Desoxycholate içeren besiyerleri laktoz pozitif Enterobacteriaceae üyelerinden E.coli, Enterobacter spp., ve Klebsiella spp. y1 laktoz negatif olan Proteus spp., ve baz1 Citrobacter spp., Salmonella spp., ve Shigella spp.yi ayrımsayabilmektedir. Ancak laktoz negatif olan türler ise ayırt edilebilmeleri çok güçtür. MDCLS besiyeri, DCLS-agar besiyerlerinin ayırdedici özelliklerini taşıması yanında, otoklavlanabilmesi, uzun süre saklanabilmesi, düşük glukoz seviyesi ile inokulasyonun hemen sonrasinda Enterobacteriaceae üyelerinin üremelerine imkan vermesi, $\mathrm{H}_{2} \mathrm{~S}$ üreten suşların teşhisini kolaylaştırması gibi üstün özelliklere sahiptir. Enterobacteriaceae üyeleri arasında Escherichia sp., laktoz, indol, MR (Metil Kırmızısı) testlerinde pozitif sonuç verirken; $\mathrm{H}_{2} \mathrm{~S}, \mathrm{VP}$ (Voges-Proskauer), üreaz, sitrat ve kapsül negatif olarak tanımlanırlar. Klebsiella spp. bakterileri ise laktoz, VP, üreaz, sitrat ve kapsül pozitif; indol, $\mathrm{H}_{2} \mathrm{~S}$, MR negatif olarak değerlendirilmektedir $[10,11]$. Selektif bir besiyeri olan MDCLS ile de Enterobacteriaceae üyelerinden E. coli, Enterobacter spp., Klebsiella spp., Citrobacter spp., Proteus mirabilis ve Proteus vulgaris'in belirgin bir şekilde ayırt edilebilmelerine imkan tanımaktadır.

$\mathrm{Bu}$ yapılan çalışmada Kahramanmaraş ilinde satışa sunulan lor peynirlerinde fekal kaynaklı Enterobacteriaceae üyelerinden E.coli ve Klebsiella spp. MDCLS besiyeri kullanılarak izolasyonu ve teşhisi yapılmaya çalışılmış ve izole edilen bu mikroorganizmaların antibiyotiklere karşı sahip oldukları direnç profillerinin belirlenmesi amaçlanmıştır.

\section{MATERYAL VE METOT}

\subsection{Lor Peyniri Örneklerinin Temini}

$\mathrm{Bu}$ çalışmada Kahramanmaraş il merkezinde bulunan market ve pazarlarda satışa sunulan lor peyniri örneklerinden randomize olarak 30 adet örnek alınmıstır. Çeşitli tezgahlarda satılan lor peynirlerinden 250'şer gram alınıp steril jelatin poşetlerle soğuk zincir yöntemi ile laboratuvara getirilmiş, $+4^{\circ} \mathrm{C}$ de saklanmış ve 24 saat içinde besiyerine ekim işlemleri yapılmıștır.

\subsection{Mikroorganizma İzolasyonu ve Sayımı}

Lor peyniri örneklerinden mikroorganizma izolasyonu için, \%10'luk hipoklorid çözeltisi ile 20 dakika bekletilerek steril su ile durulanmış blender kavanozu içerisine $10 \mathrm{gr}$ peynir örnekleri tartılarak oda sıcaklığındaki $90 \mathrm{ml} \mathrm{lik,} \mathrm{\% 1'lik} \mathrm{Sodyum} \mathrm{sitratlı} \mathrm{dilüsyon}$ çözeltisi ile blenderda $2 \mathrm{dk}$ içerisinde homojen hale getirildi ve $10^{-3}$ 'e kadar seri dilüsyonlar hazırlandı [12].

Hazırlanan dilüsyonlardan toplam bakteri sayımı için Plate Count Agar'a, Enterobacteriaceae üyesi bakterilerin izolasyonu için Mc Konkey ve Modified 
Desoxycholate Citrate Lactose Sucrose (MDCLS) agara 1 'er ml ekim yapıldı [9]. Ekim yapılan plaklar $37^{\circ} \mathrm{C}$ de etüvde 24-48 saat süre ile inkübasyona bırakıldı. İnkübasyon sonunda izole edilen mikroorganizmalar koloni morfolojilerine göre değerlendirilerek $E$. coli ve K. pnuemoniae olanlar $-20^{\circ} \mathrm{C}$ de stokland $[9]$.

Toplam mezofilik aerobik bakteri sayısını belirlemek için Plate count agara yaptı̆̆ımız ekimin sonucunda üremede oluşan koloni sayımı ile yapıldı $[13,14]$ ve sonuçlar koloni oluşturan birim (kob ml-1) olarak değerlendirildi [6].

MDCLS agarda bildirimine göre 'koyu pembe-kırmızı renkli, mat; etrafı yoğun ve geniş presipitasyon zonlu 1,5-2,0 mm çapında yassı koloniler E.coli' olarak ve 'büyük, ortası pembe-kırmızı, etrafı beyaz zonlu; tümsek ve mukoid, çevresi ise zayıf presipitasyon veya presipitasyonsuz, 1,5-3,0 $\mathrm{mm}$ çapındaki koloniler ise Klebsiella spp'. şeklinde değerlendirilmiştir [9]. Koloni görünümlerine göre cins seviyesinde teşhis edilen E.coli ve Klebsiella spp. suşları öze yardımı ile saf kolonilerden Nutrient Broth'a ekilerek $18-24$ saat $37^{\circ} \mathrm{C}$ de inkübasyona bırakıldı ve daha sonraki kullanımları için eğik katı agarda stokları yapılmıştır.

\subsection{Antibiyogram Testi}

Saf kültür olarak elde edilen bakteri suşlarının kullanılan antibiyotiklere karşı duyarlılıkları Kirby-Bauher disk difüzyon yöntemi ile saptand1. Nutrient Broth'da inkübe edilen bakteriler 0,5 MacFarland $\left(1,5 \times 10^{8} \mathrm{Kob} \mathrm{ml}^{-1}\right)$ bulanıklılık standardına göre ayarlandı. Standart bakteri süsüpansiyonundan $100 \mu \mathrm{l}$ alınıp $4 \mathrm{~mm}$ kalınlığında Müeller Hinton Agar petrilerine transfer edildi ve steril drigalski çubukları ile ekim yapıldı. Antibiyotik diskler yerleştirilmeden önce petriler $10 \mathrm{dk}$ etüvde bekletildi. Aseptik kurallar göz önünde tutularak, ekim yapılan besiyerlerine antibiyotik diskleri yerleştirildi. 18-24 saat $37{ }^{\circ} \mathrm{C}$ de inkübe edildikten sonra disklerin etrafinda üreme görülmeyen zon çapları ölçülerek CLSI kriterlerine (CLSI, 2012) göre hassas veya dirençlidir diye değerlendirmesi yapıldı [15].

\section{BULGULAR}

\subsection{Toplam Koliform Sayıları}

Çalışmada 30 adet lor peyniri numunesine ilişkin toplam koliform miktarları Tablo 1'de gösterilmektedir.

Tablo 1. Lor peyniri örneklerinde bulunan bakteri miktarları.

\begin{tabular}{|c|c|c|c|}
\hline \multirow{2}{*}{ Örnek No } & \multicolumn{3}{|c|}{ Toplam Bakteri miktarı (kob/ml) } \\
\cline { 2 - 4 } & PCA & McKonkey & MDCLS \\
\hline 1 & 115 & 50 & 30 \\
\hline 2 & 50 & 61 & 35 \\
\hline 3 & 68 & 18 & 26 \\
\hline 4 & 135 & 70 & 78 \\
\hline 5 & 108 & 25 & 45 \\
\hline 6 & 128 & 45 & 35 \\
\hline 7 & 137 & 62 & 70 \\
\hline 8 & 102 & - & - \\
\hline
\end{tabular}

\begin{tabular}{|c|c|c|c|}
\hline 9 & 187 & 59 & 47 \\
\hline 10 & 93 & 39 & 25 \\
\hline 11 & 157 & 72 & 52 \\
\hline 12 & 160 & 48 & 38 \\
\hline 13 & 129 & 52 & 20 \\
\hline 14 & 170 & 67 & 45 \\
\hline 15 & 197 & 46 & 53 \\
\hline 16 & 178 & 35 & 65 \\
\hline 17 & 108 & 52 & 47 \\
\hline 18 & 132 & 42 & 34 \\
\hline 19 & 157 & 30 & 64 \\
\hline 20 & 117 & 32 & 27 \\
\hline 21 & 125 & 40 & 41 \\
\hline 22 & 170 & 52 & 39 \\
\hline 23 & 119 & 36 & 54 \\
\hline 24 & 190 & 39 & 45 \\
\hline 25 & 107 & 55 & 17 \\
\hline 26 & 98 & 39 & 23 \\
\hline 27 & 186 & 47 & 35 \\
\hline 28 & 151 & 24 & 67 \\
\hline 29 & 201 & 32 & 41 \\
\hline 30 & 139 & 43 & 35 \\
\hline
\end{tabular}

Kob/ml: Koloni oluşturan birim/mililitre.

MDCLS ve McKonkey agara ekimi yapılan kültürlerden elde edilen verilere göre lor peyniri örneklerinde $\% 49,1$ E.coli, \%26,3 K. pneumoniae, \%17,5 Enterobacter sp, $\% 7.1$ oranında Citrobacter sp. tespit edildi (Tablo 2).

Tablo 2. Lor peyniri Örnekleri toplamında izole edilen bakteri türleri ve oranları.

\begin{tabular}{|l|l|}
\hline Bakteri & Yüzde (\%) \\
\hline E.coli & 49,1 \\
\hline Kelbsiella spp. & 26,3 \\
\hline Enterobacter spp. & 17,5 \\
\hline Citrobacter spp. & 7,1 \\
\hline
\end{tabular}

\subsection{E. coli ve Klebsiella pneumoniae Bakterilerinin Antibiyotik Duyarlılıkları}

İdentifikasyonları yapilan Enterobacteriaceae familayasına ait $74 \mathrm{E}$. coli ve $17 \mathrm{~K}$. pneumoniae suşlarının antimikrobiyal maddelere karşı hassasiyetleri disk difüzyon metodu kullanılarak tespit edildi. Tespit edilen zon çaplarına göre birçok dirençli bakteri türü belirlendi.

Çalışmamızda izole edilen 74 adet E. coli suşunun direnç oranları en yüksek \%88 ile cefuroxime karşı belirlendi. Diğer direnç dağılımı sırasıyla, \% 79 amoksisilin/klavulanikasite, \%67 ampisillin/sulbaktama, $\% 54$ gentamisine, $\% 48$ tetrasikline, $\% 30$ oflaksine, $\% 30$ nitrofurantoine, $\% 23$ streptomisine, $\% 20$ seftriaksona, $\% 2$ siproflaksine, \%1 sefepime karşı tespit edildi ancak levoflaksine karşı bir direnç tespit edilmedi.

İzole edilen 17 adet $K$. pneumoniae suşlarında direnç oranları, en yüksek \%70 ile tetraksikline karşı belirlendi. Diğer direnç dağılımı sırasıyla, \%64 sefepime, \%59 
gentamisine, $\% 58$ oflaksine, $\% 53$ nitrofurantoine, $\% 52$ siproflaksine, \%47 amoksisilin/klavulanikasite, \%42 ampisillin/sulbaktama, \%35 streptomisine, \%30 sefuroksime, \%29 levoflaksine, \%23 seftriaksona karş1 direnç tespit edildi.

Tablo 3. İzole Edilen Suşların Antibiyotik Direnç Oranları

\begin{tabular}{|l|l|l|}
\hline \multirow{2}{*}{ Antibiyotik } & $\begin{array}{l}\text { İzole Edilen Suşların Antibiyotik } \\
\text { Direnç Oranları }\end{array}$ \\
\cline { 2 - 3 } & E.coli (n:74) & $\begin{array}{l}\text { K.pneumoniae } \\
\text { (n:17) }\end{array}$ \\
\hline Cefuroxime & $\% 88$ & $\% 30$ \\
\hline Ofloxain & $\% 30$ & $\% 58$ \\
\hline Nitrofurantoin & $\% 30$ & $\% 53$ \\
\hline Tetracycline & $\% 48$ & $\% 70$ \\
\hline Gentamicin & $\% 54$ & $\% 59$ \\
\hline Ciprofloxacin & $\% 2$ & $\% 52$ \\
\hline Streptomycin & $\% 23$ & $\% 35$ \\
\hline Amoxicillin/Clavulanicacid & $\% 79$ & $\% 47$ \\
\hline Cefepime & $\% 1$ & $\% 64$ \\
\hline Ampicillin/Sulbactam & $\% 67$ & $\% 42$ \\
\hline Levofloxacin & - & $\% 29$ \\
\hline Ceftriaxone & $\% 20$ & $\% 23$ \\
\hline
\end{tabular}

n: Toplam izolat sayısı

Genellikle patojen olmayan E. coli insan ve hayvanların bağırsak florasında bulunan bir bakteridir. Bunun yanı sira bazı E. coli serotipleri patojen özellik göstermektedirler. $\mathrm{Bu}$ serotipler ile gidaların kontaminasyonu sonucu gida zehirlenmelerine, hastalıklara hatta salgınlara yol açabilmektedir. Koliform grubundan olan $K$. pneumoniae, pnömoni, safra kesesi, üriner sistem enfeksiyonları gibi çeşitli hastalıkların etkenidir [16]. Nazem ve Saleh, 1994 yılında Misir'da peynirler üzerine yapılan bir araştırma yapmışlar ve 25 Ras peynirinin \%40'ında koliform mikroorganizma, \%32'sinde E. coli saptamışlardır [17]. Orta ve Batı Brezilya'da çĭg sütlerden yapılan peynirlerde, 50 adet peynir örneğinden 48 (\%96) inde E. coli belirlenmiştir [18]. Ladan ve Reza, İran'da yaptıkları çalıșmada taze peynirlerde topladıkları 77 adet örnekten 76 adedinde (\% 98,70) enteropatojenik E. coli (EPEC) izole ettiklerini bildirmişlerdir [19].

Demirci ve ark.nın Tekirdağ'da yaptıkları çalışmada 17 lor peyniri örneğinden 16 (\%94,11)'sında koliform bakteri üremesi tespit etmişlerdir [20]. Doğan, 2001'de yaptığ bir çalışmada ise, 97 adet beyaz peynirde, $\% 78,4$ oranında koliform, \%75,3 oranında fekal koliform ve $\% 72,2$ oranında E. coli izole ettiklerini bildirmiştir [21]. Baz ve ark., 2003 yilında Kars'ta 100 çiğ süt ve 100 taze beyaz peynir örneği; koliform grubu bakteri, E. coli O157:H7 yönünden incelemişler ve incelenen süt örneklerinin tamaminda koliform grubu bakteri, \%96'sında ise E. coli tespit etmişler. Örneklerin hiçbirinde E. coli O157:H7'ye rastlanılmadığını bildirmişlerdir [22].

Ağaoğlu ve Alemdar, 2004'te Van'da tüketime sunulan dondurmalarda halk sağl1 patojen bakterilerin varlığını araştırmışlar. Çalışmada çeşitli pastanelerden sağlanan toplam 75 adet dondurma örneğinin \%8'inde L. monocytogenes, \%25,3'ünde K. pneumoniae, \%17.3'ünde Salmonella spp., \%13,3'ünde
E. coli ve $\% 13,3$ 'ünde koagulaz (+) S. aureus tespit etmișlerdir. Örneklerin \%34,7'sinde patojen bakteriye rastlanmamıştır. Sonuç olarak, incelenen dondurma örneklerinin \%65,3'ü mikrobiyolojik yönden Türk Standartlarında bildirilen kriterlere uygun olmadığını tespit etmişlerdir [23].

Kalkan ve ark. nın Ankara'daki marketlerden aldıkları beyaz peynir numunelerin \% 64'ünde koliform bakteri, $\% 22$ 'sinde $E$. coli ve \% 6'sinda $K$. pneumoniae izole etmiştir [24]. Savaşan ve Göksoy'un Aydın'da yaptıkları çalışmada, 100 adet peynir örneğinden $\% 22$ oranında $E$. coli tanımlamışlardır [25].

Atabey 2011 'de yaptığ 1 çalışmada 50 adet kaşar peyniri, 50 adet beyaz peynir örneği incelemiştir. Çalışmanın sonuçlarına göre beyaz peynirlerin \%22'sinin E.coli ve $\% 16$ 'sının $S$. aureus ile kontamine olduğu tespit etmiştir. Kaşar peynirlerinden sadece \%4'ünün $S$. aureus ile kontamine olduğunu tepsi t etmiştir. İzole edilen suşlara yapılan antibiyogram testi sonucunda, E. coli suşlarının antibiyotik direnç oranları sırasıyla \%100 penisilin, $\% 55$ streptomisin, \% 55 gentamisin, \%18 amoksisilinklavulonik asit ve \% 0 enroflaksasin olarak belirlemiştir [26].

Özadam tarafindan İstanbul'da yapılan çalışmada toplam 83 adet peynir örneklerinde GSBL ve AmpC tipi betalaktamazları üreten $\% 27,8 \mathrm{~K}$. pneumoniae, $\% 27,8 \mathrm{H}$. alvei, \%22,2 E. coli, \%11,2 K. oxytoca, \%5,5 E. cloacae ve \%5,5 Citrobacter spp. olarak karakterize edilmiştir [27].

Bizim çalıșmamızda, E. coli açısından lor peyniri örneklerinden elde ettiğimiz sonuç \% 49,1 Brezilya'da Panetto ve ark.nın \%96, İran'da Ladan ve Reza'nın $\% 98,70$, Demirci ve ark.nın \%94,11 ve Baz ve ark.nın yaptığı çalışmada elde ettiği sonuçlarından daha düşük olmakla birlikte Özadam'ın \%22,2, Savaşan ve Göksoy $\% 22$, Kalkan ve ark. \%22, Ağaoğlu ve Alemdar \% 13,3 ve Nazem ve Saleh'in \%32 sonuçlarından daha yüksek oranlarda çıkmıştır.

Örneklerden izole edilen $K$. pneumoniae sonucu (\% 26,3), Özadam'ın \%27,8, A ̆gaoğlu ve Alemdar'ın sonuçlarına benzer fakat Kalkan ve arkadaşlarının sonuçlarından yüksek oranda elde edilmiştir.

Elde ettiğimiz sonuçların yüksek oranlarda çıkmasının en önemli etkeninin peynir yapımının geleneksel yöntemler ile hijyenik olmayan ortamlarda yapılması ve taşınması olduğunu düşünmekteyiz. Diğer bir etken ise, lor peynirinin salamura peynirleri gibi tuzlu ortamda olmaması ve olgunlaşma sürecinden geçmemesinden dolayı mikroorganizmaların hızlı üremesi için uygun ortam olmasından kaynaklandığını düşündürmektedir.

K. pneumoniae suşlarında ESBL'ye bağlı üçüncü kuşak sefalosporin direnci sık karşılaşılan bir durumdur ve çoğunlukla aminoglikozid direnci ile birliktedir [28]. Avrupa'da ozellikle ESBL üreten $E$. coli ve $K$. pneumoniae suşları icin yapılan çok merkezli bir çalışmada Türkiye-Yunanistan kolunda diğer 
aminoglikozidlere oranla isepamisin bu suşlarda daha duyarlı bulunmuştur (The Aminoglycosie Resistance Study Groups, 1995). Amikasin, gentamisin ve tobramisine karşı direnç yüzdelerinin tespit edildiği MYSTIC çalışmasında $K$. pneumoniae için sırasıyla \% 6,5, \% 34 ve \% 36'lik direnç yüzdeleri elde edilmiştir [29].

Bu çalışmada, E. coli ve $K$. pneumoniae tetrasiklin, penisilin, aminoglikozid grubuna karşı yüksek oranda direnç geliştirdiği görülmektedir. Sefalosporin grubuna karşı E. coli, beta laktam, kinolonlar grubu ve imidazol türevlerine karşı ise $K$. pneumoniae daha yüksek oranda direnç kazandığı görülmektedir. E.coli kionolonlardan levoflaksin ve siproflaksin, beta laktamlardan sefepime karşı duyarlı olduğu görülmüştür.

\section{SONUC}

Tedavisi daha zor yapılan ve güç enfeksiyonlara neden olan GSBL üreten $E$. coli, K. pneumoniae ve dolayısı ile direnç geliştiren Gram negatif enterik bakterilerin direnç profilleri, araştırmacılar tarafından çeşitli zamanlarda araştırılmalıdır, enfeksiyonların tedavisinde tercih edilen geniş spektrumlu beta laktam antibiyotiklerin kullanılmasında araştırma sonuçları göz önüne alınmalıdır. Çalışmamızda lor peynirinin tüketicinin sofrasına gelinceye kadar hijyen kurallarına dikkat edilmediğinin çarpıcı sonuçları elde edilmiştir. $\mathrm{Bu}$ durumun da ürünün barındırdığı mikroorganizmalar ile aktarılan antibiyotik dirençli genlerin de çoğul direnci arttırabileceği anlaşılmaktadır.

Toplumda yaygın olarak kullanılan bu ürün gerekli hijyen koşullarına dikkat edilmediğinde risk faktörüne dönüşmektedir.

Süt sağım aşamasından peynir yapımı ve tüketim aşamasına kadar hijyen kurallarına uyulması ve soğuk zincir vb. yöntemler ile taşınmasının önemi anlaşılmıştır. İçerisinde gelişen mikroorganizmalar insan sağlığına zarar verirken bu mikroorganizmaların antibiyotiklere karşı oluşturdukları direnç ise daha ciddi sorunlara yol açmaktadır. Özellikle antibiyotik dirençliliği olan bakteriler yaygın kullanımı olan bu ürünle birçok insanın bünyesinde barınmaya başlaması ile birçok antibiyotiğin yer aldığ 1 tedavi biçimine cevap vermeyen enfeksiyon hastalıklara neden olması muhtemeldir.

Elde ettiğimiz veriler antibiyotik kullanımı konusunda toplum olarak bilinçlenmeye ihtiyacımız olduğunu ve daha kontrollü kullanılmasını göstermektedir. Bilinçsiz antibiyotik kullanımı zararlı mikroorganizmaların dirençliliğini arttırmış ve bu döngü günden güne artmaktadır. Özellikle hayvanların hızlı büyümelerini sağlamak amacı ile kullanılan antibiyotikler ve bu hayvanların ya da onlardan üretilen ürünlerin tüketimi dirençli bakterilerin yaygınlaşmasına neden olmuştur. $\mathrm{Bu}$ sonuçlara göre antibiyotik kullanımın hem tedavilerde hem de hayvanlardan daha fazla verim elde etmek kullanılmasında daha kontrollü olunması gerekliliğini bir kez daha ortaya koymaktadır.

\section{Teşekkür}

Desteklerinden dolayı KSU BAP birimine Teşekkür ederiz (2015/3-26 YLS).

$\mathrm{Bu}$ çalışma International Medical and Biological Sciences Congress 2018 Niğde'de özet bildiri olarak sunulmuştur.

\section{KAYNAKLAR}

[1] Halkman AK. Merck Gida Mikrobiyolojisi Uygulamaları. Başak Matbaacılık, AnkaraTürkiye. 2005.

[2] Arıkan B, Aygan A. Resistance Variations of 3rd Generation of Cephalosporins in Some of the Enterobacteriaceae Members in Hospital Sewage. Int J Agric Biol. 2009; 11(1): 93-6.

[3] Metin M. Süt Teknolojisi-Sütün Bileşimi ve İşlenmesi. Ege Üniversitesi Mühendislik Fakültesi Yayınları No: 33, s. 801, İzmir-Türkiye. 2001.

[4] Köşker Ö, Tunail N. Süt ve Mamulleri Mikrobiyolojisi ve Hijyeni Uygulama Klavuzu. Ankara Üniversitesi Ziraat Fakültesi Yayınları No: 985, Uygulama Kilavuzu No: 217, AnkaraTürkiye.1985.

[5] Anonim, Türk İstatistik Enstitüsü, http://www.tuik.gov.tr/Beslenme/index. html (Erişim Tarihi: 08.09.2006).

[6] Dığrak M, Yılmaz Ö, Çelik S, Özçelik S. Elazığ'da Satışa Sunulan Taze Beyaz Peynirlerin Mikrobiyolojik Kalitesi ve Yağ Asitleri Analizi. Turk J Biol. 1996; 20: 221-30.

[7] Greiner R, Konietzny U. Modern Molecular Methods (PCR) in Food Control: GMO, Pathogens, Species Identification, Allergens, The World of Food Science, 7th Simposio Latino Americano de Ciencia de Alimentos, 2007. 4-7 November, Brazil.

[8] Torlak E. Gida Mikrobiyolojisinde Enterobacteriaceae Üyeleri İçin Kromojenik ve Florojenik Besiyerleri. Türk Hij Den Biyol Derg. 2011; 68 (1): 49-58.

[9] Arıkan B, Çolak Ö. Laktoz Pozitif Enterobacteriaceae Üyelerinin İzolasyonu İçin Geliştirilmiş Selektif Agar Besiyeri. Doğa. Turk J Biol. 1991; 15: 1-6.

[10] Costin, Die Biochemische Identifizierung der Enterobacteriaceae. Kritische Bemerkungen zu Prinzipien und Methoden. Zentralbl. Bakteriol. Parasitenk. Infektionskr. Abt. I Ref. 1969; 219: 767-837.

[11] Barrow GH, Feltham RKA. Cowan and Steel's Manual for Identification of Medical Bacteria. 3rd Ed. Cambridge University Press, Cambridge, 331. 1993.

[12] Duncan SE, Yaun BR, Sumner SS. Standart Methods for the Examination of Dairy Products. American Public Health Association press, s.249268, Washington D.C.-USA. 2004.

[13] Hausler WS. Standart Methods for the Examination of Dairy Products, 13th. Ed. American Public Health Association. Washington, D.C.1974. 
[14] Harrigan W, Hausler WS. Standart Methods for the Examination of Dairy Products, 13th. Ed. , American Public Health Association. Washington, D.C. 1974.

[15] Jesudason MV, Kantathil AJ, Balaji V. Comparison of Two Methods to Detect Carbapenemase \& Metallo- Lactamase Production in Clinical Isolates. Indian J Med Res. 2004; 121: 780-783.

[16] Erdem B. "Temel ve Klinik Mikrobiyoloji" Enterobacteriaceae, Bölüm 12 (Editör, Ustaçelebi, Ş.) Güneş Kitabevi. Ankara. 1999.

[17] Nazem AM, and Saleh, TM. Chemical and Microbiological Evaluation of Market ras Cheese. Assiut Vet Med J. 1994; 30(59): 139-144.

[18] Paneto BR, Hurrino SRP, Macedo C, Santo E, Marin JM, Occurence of toxigenic Escherichia coli in raw milk cheese in Brazil. Arquivo Brasileiro de Medicina Veterinaria e Zootecnia. 2007; 59: 508512.

[19] Ladan NM, Reza G. A Study on Enteropathogenic Escherichia coli Isolated From Domestic Iranian Soft Cheese. Veterinarski Arhiv. 2006; 76: 531-536

[20] Demirci M, Şimşek O, ve Arıcı M. Tekirdağ Piyasasında Satılan Lorların Bileşimi ve Bazı Mikrobiyolojik Özellikleri Üzerine Bir Araştırma, Gida. 1991; 16 (5): 291-294.

[21] Doğan B. Çeşitli Gidalarda Koliform, Fekal Koliform ve E.Coli Varlığı.(2). Gıda. 2001; 26, 8390.

[22] Baz E, Gülmez M, Güven A, Sezer Ç, Duman B. Kars İlinde Satışa Sunulan Çiğ Süt ve Taze Beyaz Peynirlerin Koliform Grubu Bakteri, E. coli ve E. coli O157:H7 Yönünden İncelenmesi. Kafkas Üni Vet Fak Derg. 2003; 9: 165-7.

[23] Ağaoğlu S, Alemdar S. Van'da Tüketime Sunulan Dondurmalarda Bazı Patojenlerin Varlığının Araştırılması YYÜ Vet Fak Derg. 2004; 15 (12):59-64.

[24] Kalkan A, Tansu-Aktan H, Kamber U, Ülgen MT, Mutluer B. Beyaz Peynirlerde Koliform Bakterilerin (E. coli ve K. pneumoniae) Bulunuşu Üzerinde Araştırma. AÜ Vet Fak Derg. 1991; 38 : 108-13.

[25] Savaşan S, Göksoy EÖ. Taze Peynirlerden İzole Edilen Escherichia coli Suşlarının Genotiplendirilmesi. Etlik Vet Mikrobiyol Derg. 2018; 29 (2): 127-35

[26] Atabey C. Piyasada Satışa Sunulan Peynirlerden Elde Edilen Jenerik Escherichia coli ve Staphylococcus aureus Suşlarının Antibiyotik Dirençliliklerinin Belirlenerek, Mastitis Kontrol ve Tedavi Programlarında Kullanılan Antibiyotiklerle İlişkisinin Belirlenmesi. Yüksek Lisans Tezi. Adnan Menderes Üniversitesi Sağlık Bilimler Enstitüsü 2011.

[27] Özadam A. Peynir Örneklerinden İzole Edilen Enterobakterilerde Geniş Spektrumlu betaLaktamaz (GSBL) ve AmpC Dirençlilik Durumlarının İncelenmesi. İstanbul Aydın Universitesi, Fen Bilimleri Enstitüsü, Gıda Güvenliği Programı, İstanbul, 2016.

[28] Bahar H, Esen N. Acinetobacter ve Diğer Nonfermentatif Basiller. Topcu A.W., Soyletir
G.,Doğanay M.(eds), İnfeksiyon Hastalıkları ve Mikrobiyolojisi, Nobel Tip Kitapevleri s: 6181623,2002

[29] Kiffer C, Hsiung A, Oplustil C, Sampalo J, Sakagami E, Turner P, Mendes C. MYSTIC Brazil Group. "Antimicrobial Susceptibility of Gram Negaitve Bacteria in Brazilian Hospitals: The MYSTIC Program Brazil 2003" BJID; 9(June) 2005; 216-224 